\title{
Effects of heat-treatment temperature on carbon-based composites with added illite
}

\author{
Euigyung Jeong, Jinhoon Kim and Young-Seak Lee* \\ Department of Fine Chemical Engineering and Applied Chemistry, BK21-E²M, Chungnam National University, Daejeon 305-764, \\ Korea
}

\section{Article Info}

Received 24 January 2011

Accepted 24 May 2011

*Corresponding Author

E-mail: youngslee@cnu.ac.kr

\section{Open Access}

DOI: 10.5714/CL.2011.12.2.095

This is an Open Access article distributed under the terms of the Creative Commons Attribution Non-Commercial License (http://creativecommons.org/licenses/ by-nc/3.0/) which permits unrestricted non-commercial use, distribution, and reproduction in any medium, provided the original work is properly cited.

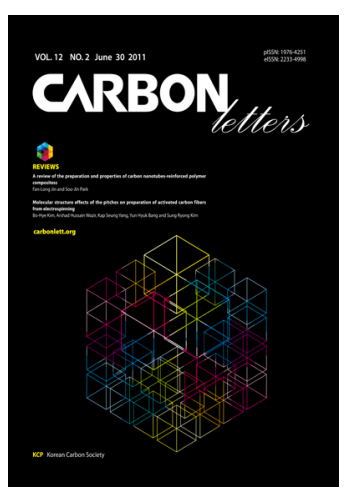

http://carbonlett.org

pISSN: $1976-4251$

elSSN: 2233-4998

Copyright $\odot$ Korean Carbon Society

\begin{abstract}
To investigate new applications for illite as an additive for carbon-based composites, the composites were prepared with and without illite at different heat-treatment temperatures. The effects of the heat-treatment temperature on the chemical structure, microstructure, and thermal oxidation properties of the resulting composites were studied. As the heat-treatment temperature was increased, silicon carbide $\mathrm{SiC}$ formation via carbothermal reduction increased until all the added illite was consumed in the case of the samples heat-treated at $2,300^{\circ} \mathrm{C}$. This is attributed to the intimate contact between the $\mathrm{SiO}_{2}$ in the illite and the phenol carbon precursor or the carbon fibers of the preform. Among composites prepared at all temperatures, those with illite addition exhibited fewer pores, voids, and interfacial cracks, resulting in larger bulk densities and lower porosities. A delay of oxidation was not observed in the illite-containing composites prepared at $2,300^{\circ} \mathrm{C}$, suggesting that the illite itself absorbed energy for exfoliation or other physical changes. Therefore, if the illite-containing $\mathrm{C} / \mathrm{C}$ composites can reach a density generally comparable to that of other $\mathrm{C} / \mathrm{C}$ composites, illite may find application as a filler for $\mathrm{C} / \mathrm{C}$ composites. However, in this study, the illite-containing $\mathrm{C} / \mathrm{C}$ composites exhibited low density, even when prepared at a high heat-treatment temperature of $2300^{\circ} \mathrm{C}$, although the thermal oxidation of the resulting composites was improved.
\end{abstract}

Key words: $\mathrm{C} / \mathrm{C}$ composites, illite, thermal oxidation, heat treatment

\section{Introduction}

Carbon fiber-reinforced carbon $(\mathrm{C} / \mathrm{C})$ composites have garnered much attention from researchers due to their outstanding mechanical properties including high strength-to-weight ratio, low density, excellent thermal stability, high thermal conductivity, low coefficient of thermal expansion, and resistance to thermal shock and ablation [1-3]. Furthermore, $\mathrm{C} / \mathrm{C}$ composites are considered promising candidates for such applications as brake discs in advanced aircrafts, heat shields for reentry vehicles, nozzles in solid rocket motors, and nose tips and leading edges in aerospace applications $[4,5]$. However, the application of $\mathrm{C} / \mathrm{C}$ composites has been limited because they begin to oxidize at temperatures greater than $450^{\circ} \mathrm{C}$ [6]. Thus, to overcome this limitation, the oxidation stability of $\mathrm{C} / \mathrm{C}$ composites must be improved.

Two approaches have generally been used to improve the oxidation stability of these composites. One approach entails coating the carbon fibers or the composite with an antioxidant layer, whereas the other involves the direct addition of antioxidant fillers into the matrix [7]. Accordingly, ceramic materials such as $\mathrm{SiO}_{2}, \mathrm{MoSi}_{2}, \mathrm{ZrB}_{2}, \mathrm{SiB}_{4}$, and $\mathrm{Si}_{3} \mathrm{~N}_{4}$ have been used to improve the oxidation stability of the composites $[8,9]$. However, these ceramic fillers are expensive and can adversely affect human health [8].

In this regard, it is worth considering the use of layered silicates (clays) in $\mathrm{C} / \mathrm{C}$ composites. Clays have drawn much interest both in academia and industry, because they can remarkably improve the mechanical properties of composite materials when used as fillers, particularly in clay/ polymer nanocomposites [10]. Similarly clays can be used in $\mathrm{C} / \mathrm{C}$ composites, another important 


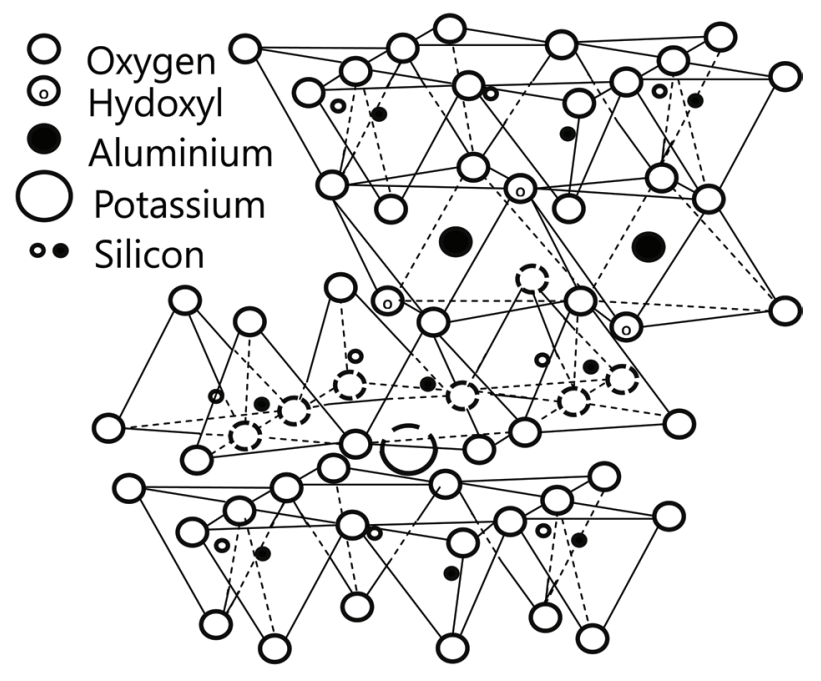

Fig. 1. Chemical structure of illite.

class of composite materials.

Among clay materials, illite is one of the most abundant on earth, and is therefore a promising clay filler candidate. The chemical structure of illite is shown in Fig. 1. Pure illite contains two $\mathrm{SiO}_{2}$ tetrahedral sheets covering a central $\mathrm{Al}_{2} \mathrm{O}_{3}$ octahedral sheet, whereas the raw illite used in this study contained quartz and kaolinite, both mainly consisting of $\mathrm{SiO}_{2}$, as impurities [11]. $\mathrm{SiO}_{2}$ and $\mathrm{Al}_{2} \mathrm{O}_{3}$ are widely used fillers that are employed to provide good thermal properties [12]. Moreover, it is possible to form $\mathrm{SiC}$ via the reaction between illite, phenol resin, and carbon fiber during the carbonization of phenol resin; this results in additional improvement in the oxidation stability of $\mathrm{C} / \mathrm{C}$ composites, as noted in our previous report [13]. Additionally, as shown in Fig. 1, illite has a layered structure, which is a characteristic feature of solid, high-temperature lubricants used to enhance the impregnation or infiltration of liquid materials, such as Si liquid slurries and polymers or pitch melts, by reducing abrasion [14]. This enhancement was also expected to improve the oxidation stability and mechanical properties of $\mathrm{C} / \mathrm{C}$ composites.

Our previous studies showed that when using illite as a filler, both the oxidation stability and the mechanical properties of $\mathrm{C} / \mathrm{C}$ composites were improved. Furthermore, the oxidation stability of the composites was also improved after physically modifying illite in the pursuit of possible novel applications of illite in $\mathrm{C} / \mathrm{C}$ composites $[13,15]$. Hence, in this study, to further investigate illite's potential use in $\mathrm{C} / \mathrm{C}$ composites, illite was added to a phenol resin carbon matrix precursor, and the mixture was impregnated only once to emphasize both the effect of the illite addition and heat treatment at different temperatures. The effects of the heat-treatment temperature on the chemical structure, microstructure, and thermal oxidation properties of the resulting illite-containing $\mathrm{C} / \mathrm{C}$ composites were investigated.

\section{Experimental}

\subsection{Materials}

Illite (1000 mesh) was provided by Yonggoong Illite Co.
(Youngdong, Korea). A needle-punched carbon preform was manufactured with $12 \mathrm{~K}$ oxy-PAN fibers and was provided by DACC Co., Ltd. (Jeonju, Korea). Resol-type phenol resin (HM2) was purchased from Kolon Chemical Co. (Gimcheon, Korea).

\subsection{Sample preparation}

Illite-containing $\mathrm{C} / \mathrm{C}$ composites were prepared in the following manner. Illite was added to the phenol resin at 0 and $10 \mathrm{wt} \%$ of the phenol-resin base and stirred for $2 \mathrm{~h}$. A needle-punched carbon preform was then impregnated with the illite/phenol

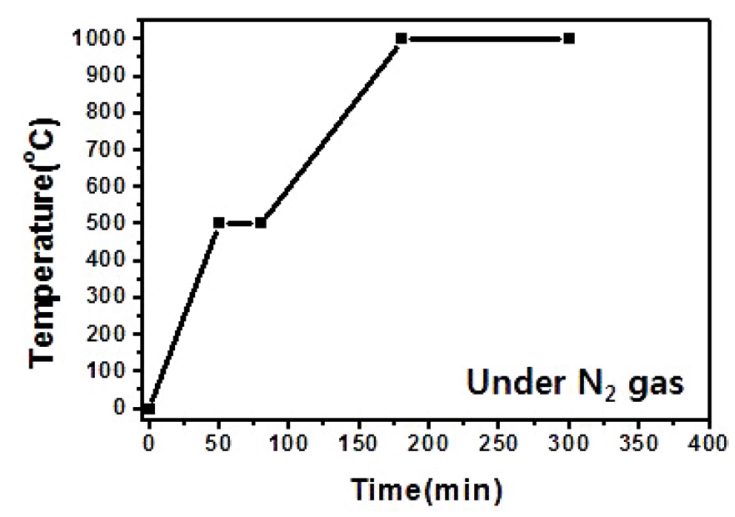

(a)

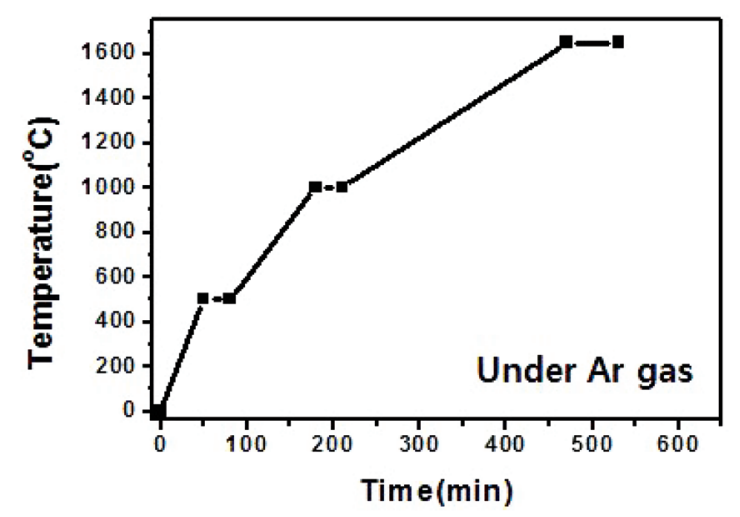

(b)

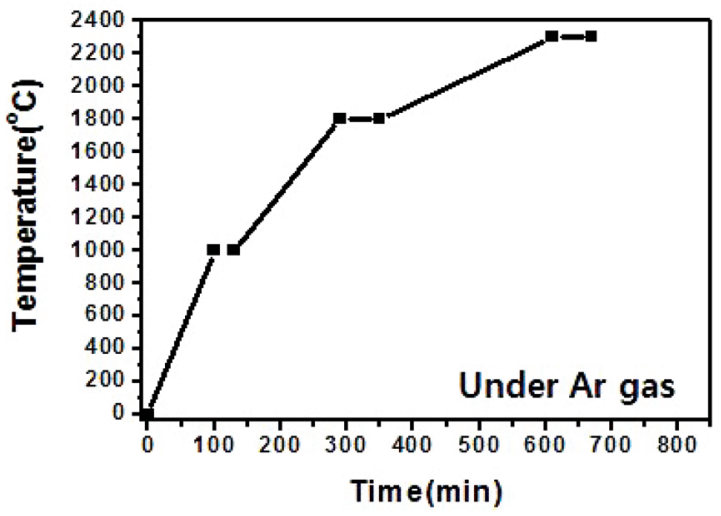

(c)

Fig. 2. Heating procedures of the $C / C$ composites prepared at different heat-treatment temperatures: (a) $1,000^{\circ} \mathrm{C},(\mathrm{b}) 1,650^{\circ} \mathrm{C}$, and (c) $2,300^{\circ} \mathrm{C}$. 
resin mixture at 0.2 bars for $10 \mathrm{~min}$. The impregnated preform was dried in a thermoreactor at $70^{\circ} \mathrm{C}$ for $3 \mathrm{~h}$. The phenol-resinimpregnated carbon preform was cured at $130^{\circ} \mathrm{C}$ for $5 \mathrm{~h}$. Finally, the phenol resin/carbon composite was carbonized at 1,000 , 1,650 , or $2,300^{\circ} \mathrm{C}$ using the procedure illustrated in Fig. 2.

\subsection{Characterization of the prepared $\mathrm{C} / \mathrm{C}$ com- posites}

X-ray diffraction experiments (XRD, D/MAX-2200 Ultima/PC; Rigaku International Corporation, Japan) were performed to investigate the chemical changes in the $\mathrm{C} / \mathrm{C}$ composites (in particular, the formation of $\mathrm{SiC}$ ) in response to different heat-treatment temperatures. Scanning electron microscopy (SEM, JSM 700F; JEOL Co., Japan) was used to observe the effect of different heat-treatment temperatures on the microstructures of the prepared $\mathrm{C} / \mathrm{C}$ composites. The bulk densities and porosities of the prepared composites were evaluated using the ASTM C20 method. A thermogravimetric analysis (TGA, TGA/SDTA851; Mettler-Toledo, Switzerland) was performed to evaluate the thermal oxidation stability of the prepared samples at a heating rate of $5^{\circ} \mathrm{C} / \mathrm{min}$ in air.

\section{Results and Discussion}

\subsection{Effect of the heat-treatment temperature on the chemical structures of the prepared composites}

Fig. 3 shows the XRD patterns of the illite-containing C/C composites prepared with and without illite at different heat-treatment temperatures. In Fig. $3 a$ and b, the peak at $26^{\circ}$, resulting from the (ll $\left.\begin{array}{lll}0 & 2\end{array}\right)$ phase of the crystalline carbon, was observed in all XRD patterns of the prepared composites, and the peak became sharper as the heat-treatment temperature was increased due to the increased crystallinity of the carbon materials. With a heat-treatment temperature of $1,000^{\circ} \mathrm{C}$, an $\mathrm{SiO}_{2}$ peak at $19.88^{\circ}$, characteristic of the illite, was observed without any $\mathrm{SiC}$ peak. At heat-treatment temperatures of 1,650 and $2,300^{\circ} \mathrm{C}$, three peaks were observed, at

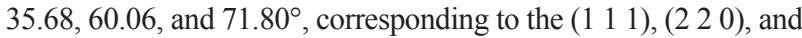
(3 11 1) peaks of $\beta$-SiC, respectively; these peak positions are in good agreement with the findings of other studies [16-18]. $\beta$-SiC was formed as a product of the carbothermal reaction as a result of intimate contact between the $\mathrm{SiO}_{2}$ in the illite and the phenol resin in the precursor or carbon fibers in the preform $[13,15]$. It was also observed that the $\beta$-SiC peaks became sharper as the heat-treatment temperature was increased. Furthermore, as shown in Table 1 , it was observed that the formation of $\beta-\mathrm{SiC}$ in the illite-containing $\mathrm{C} / \mathrm{C}$ composites increased by approximately $57 \%$ when the heat-treatment temperature was increased from $1650^{\circ} \mathrm{C}$ to $2300^{\circ} \mathrm{C}$. It was also observed that the $\mathrm{SiO}_{2}$ peak essentially disappeared at the heat-treatment temperature of $2300^{\circ} \mathrm{C}$, suggesting that most of the illite had reacted to form $\mathrm{SiC}$.

Other new, small peaks at $33.84,41.34$, and $56.10^{\circ}$ were also observed in the sample patterns. These peaks corresponded to $\alpha$-SiC. According to a computer simulation by Pujar and Cawley [19], these peaks arise from stacking faults, which are crystallographic defects in the stacking sequence [17]. Another study reported that these peaks arise from the presence of the $2 \mathrm{H}$ polytype [20], which

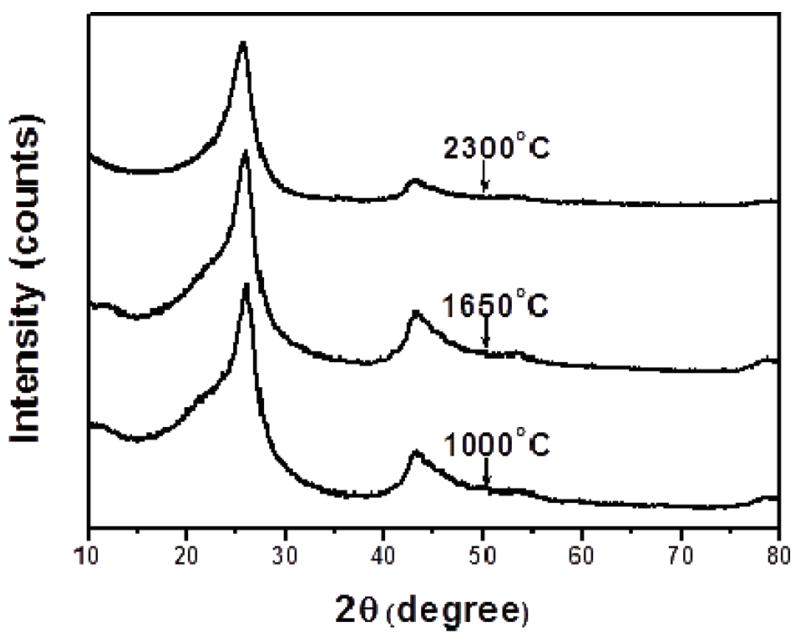

(a)

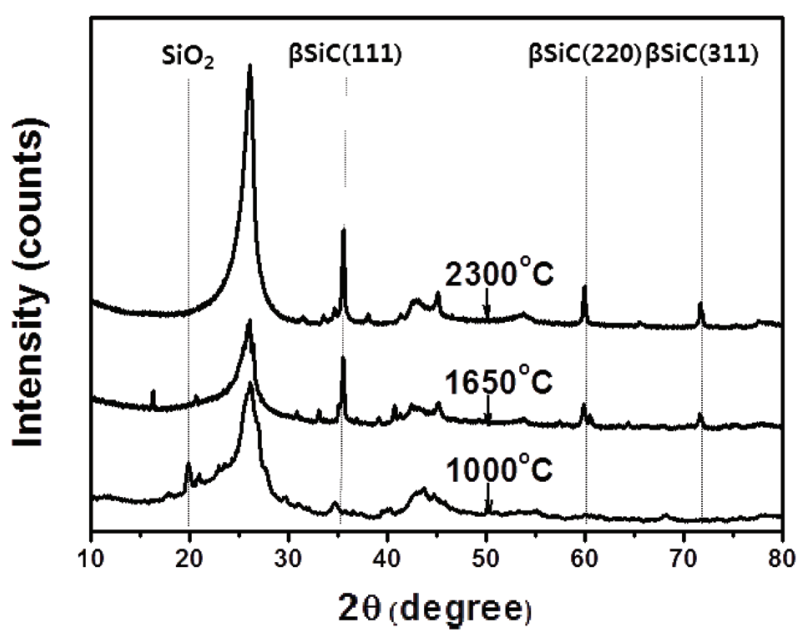

(b)

Fig. 3. X-ray diffraction patterns of the composites prepared (a) without and (b) with illite at different heat-treatment temperatures.

Table 1. Quantitative analysis of $\beta$-SiC in the XRD patterns shown in Fig. 3.

\begin{tabular}{ccc} 
Heat-treatment temperatures & $\mathbf{S i O}_{2}$ & $\boldsymbol{\beta}$-SiC \\
\hline $1,000^{\circ} \mathrm{C}$ & $3.6 \%$ & - \\
$1,650^{\circ} \mathrm{C}$ & $2.6 \%$ & $6.0 \%$ \\
$2,300^{\circ} \mathrm{C}$ & $0.1 \%$ & $9.4 \%$
\end{tabular}

XRD: X-ray diffraction.

is composed of two planar elements stacked alternatively, inducing a much stronger reflection peak near $38.3^{\circ}$. However, that peak was not observed in the XRD patterns of the samples, indicating that these peaks resulted from stacking faults.

\subsection{Effect of heat-treatment temperature on the microstructures of the prepared composites}

The microstructures of the prepared composites are shown 


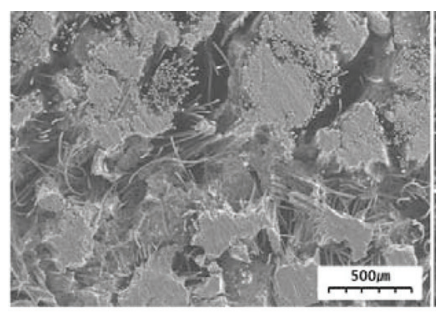

(a)

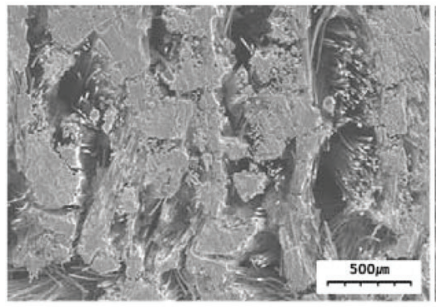

(d)

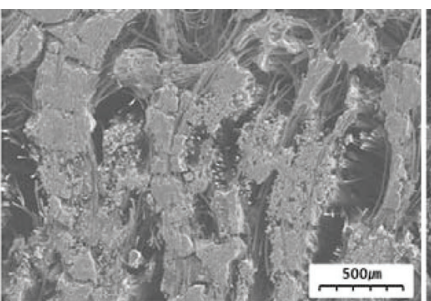

(b)

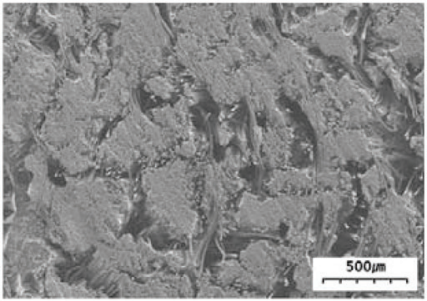

(e)

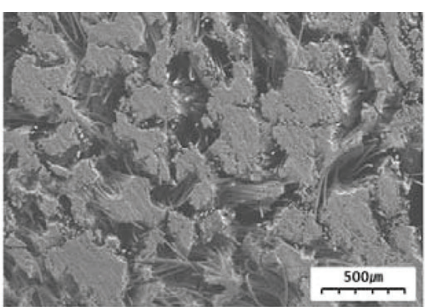

(c)

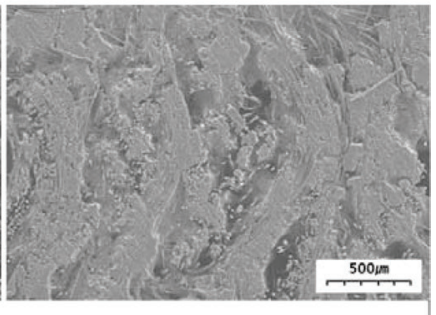

(f)

Fig. 4. Microstructures of the composites prepared at different heat-treatment temperatures: (a) $1,000^{\circ} \mathrm{C}$ with $0 \%$ illite, (b) $1,650^{\circ} \mathrm{C}$ with $0 \%$ illite, (c) $2,300^{\circ} \mathrm{C}$ with $0 \%$ illite, (d) $1,000^{\circ} \mathrm{C}$ with $10 \%$ illite, (e) $1,650^{\circ} \mathrm{C}$ with $10 \%$ illite, and (f) $2,300^{\circ} \mathrm{C}$ with $10 \%$ illite.

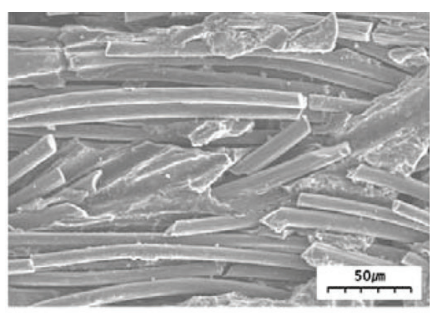

(a)

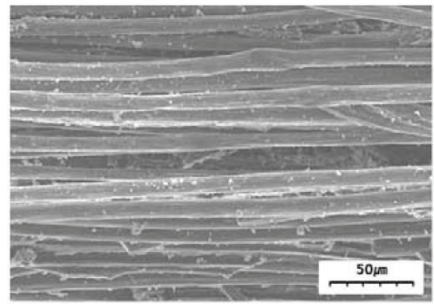

(d)

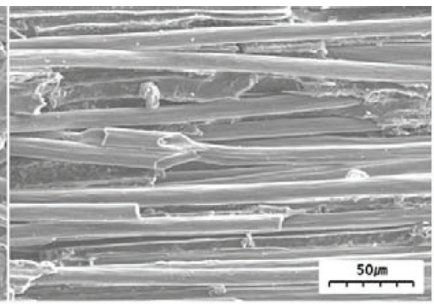

(b)

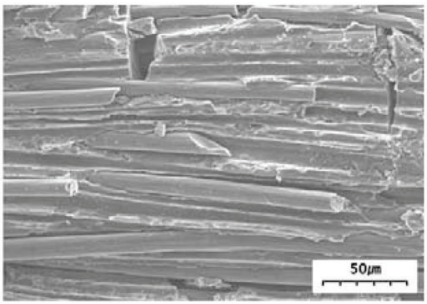

(e)

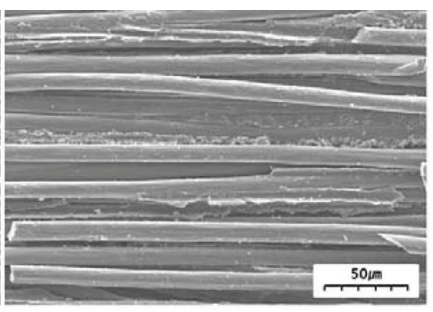

(c)

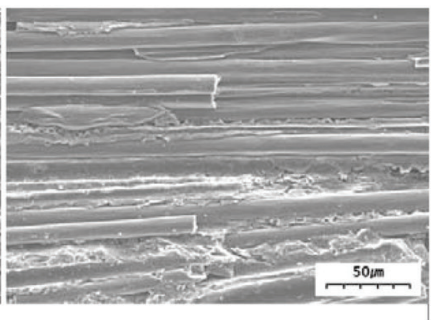

(f)

Fig. 5. Microstructures of the composites prepared at different heat-treatment temperatures: (a) $1,000^{\circ} \mathrm{C}$ with $0 \%$ illite, (b) $1,650^{\circ} \mathrm{C}$ with $0 \%$ illite, (c) $2,300^{\circ} \mathrm{C}$ with $0 \%$ illite, (d) $1,000^{\circ} \mathrm{C}$ with $10 \%$ illite, (e) $1,650^{\circ} \mathrm{C}$ with $10 \%$ illite, and (f) $2,300^{\circ} \mathrm{C}$ with $10 \%$ illite.

in Figs. 4 and 5. At the lowest magnification $(50 \times)$, it can be observed in the SEM images in Fig. 4 that the $\mathrm{C} / \mathrm{C}$ composites with illite (Fig. 4d-f) contained fewer pores than those without illite (Fig. 4a-c) when prepared at the same heat-treatment temperature. At higher magnification $(500 \times)$, the SEM images in Fig. 5 show that the composite without illite contained more voids between its constituent fibers and more interfacial cracks between its fiber bundles and matrix (Fig. 5a-c) compared with the composite incorporating illite (Fig. 5d-f). Comparison of each set of two composites prepared at the same heat-treatment temperature also suggests that the composites with illite were denser than those without illite (Fig. 5). These observations were confirmed by measuring the bulk densities and the porosities of the composites using the ASTM C20 method; the results are shown in Fig. 6. The composites with illite exhibited bulk densities $11-20 \%$ higher than those without illite, as shown in Fig. 6a, whereas the composites with illite exhibited porosities $10-18 \%$ lower than those without illite, as shown in Fig. 6 b.

These results may be attributed to the lubricating effect of illite. Illite is a silicate with a layered structure, as shown in Fig. 1. Layered materials, such as graphite, boron nitride, molybdenum disulfide, and even clay-based talc, are often used as solid lubricants 


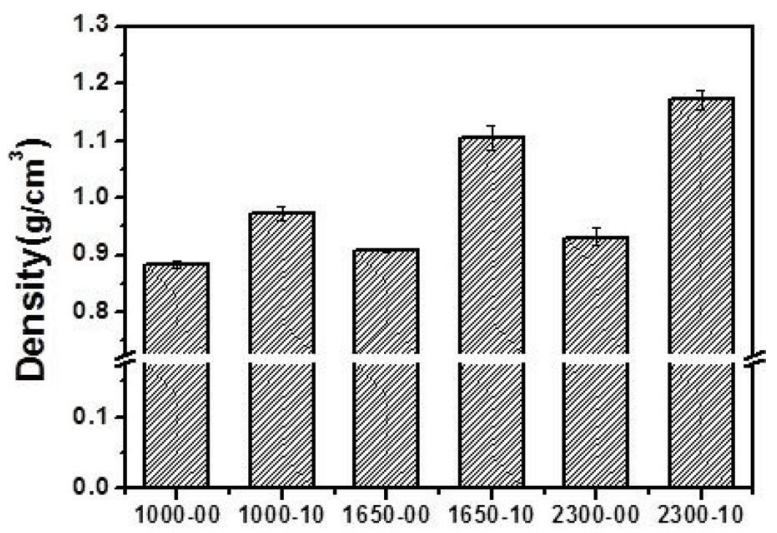

(a)

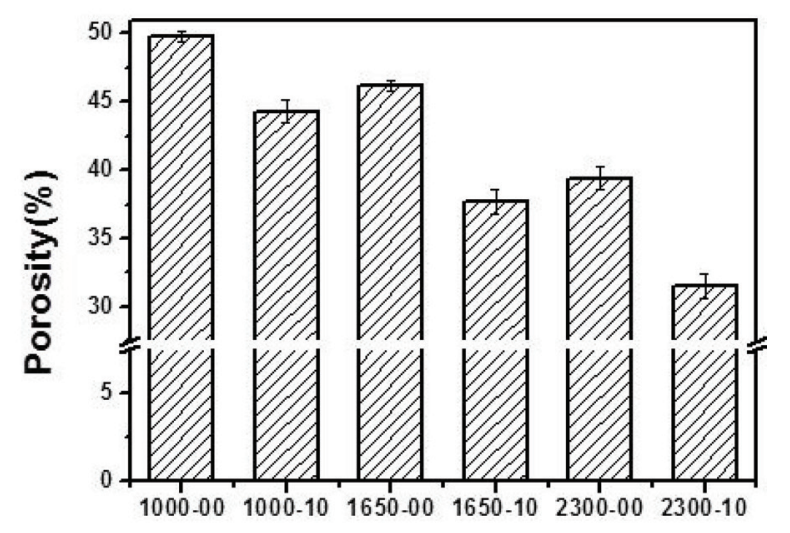

(b)

Fig. 6. Bulk densities and porosities of the composites prepared at different heat-treatment temperatures and with different amounts of added illite.

$[14,21,22]$. Therefore, illite may reduce the abrasion between the liquid phenolic resin and the carbon preform [22], enhancing the impregnation of the phenol resin into the carbon preform. This enhanced impregnation would result in fewer pores, voids, and interfacial cracks in the composites and subsequently lead to composites with greater bulk densities and lower porosities. Here, it is important to note that the densities of the composites also increased as the heat-treatment temperature was increased. This increase was due to the increase in crystallinity of the carbon material with increasing heat-treatment temperature [23].

\subsection{Effect of heat-treatment temperature on the thermal oxidation stability of the prepared composites}

Fig. 7 illustrates the thermal oxidation stability of the prepared composites in air. As the heat-treatment temperature was increased, the initial decomposition temperature (IDT) by thermal oxidation also increased due to the increasingly crystalline structure of the carbon material [23]. At the same heat-treatment temperature, the IDT was higher in the composites with illite than in those without illite. For example, at the heat-treatment temperature of $2,300^{\circ} \mathrm{C}$, the IDT of the composite with illite increased by approximately $30^{\circ} \mathrm{C}$ over the corresponding compos-

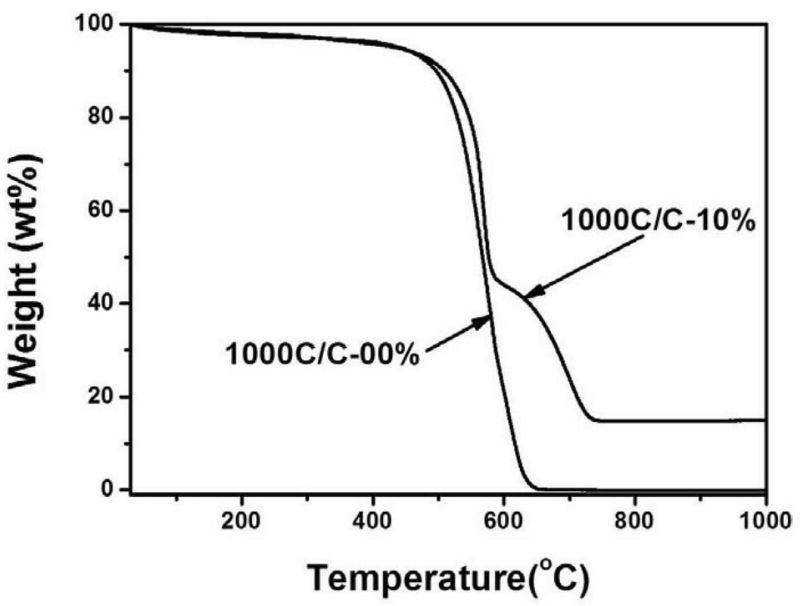

(a)

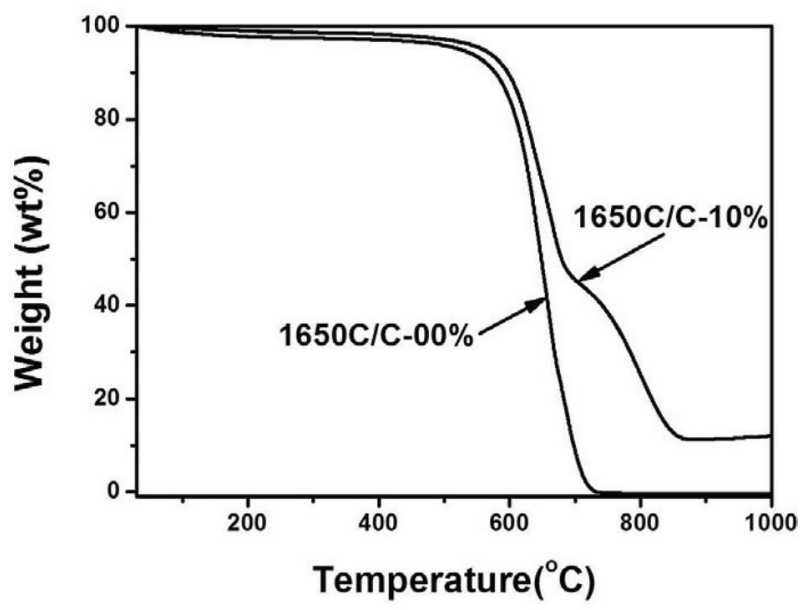

(b)

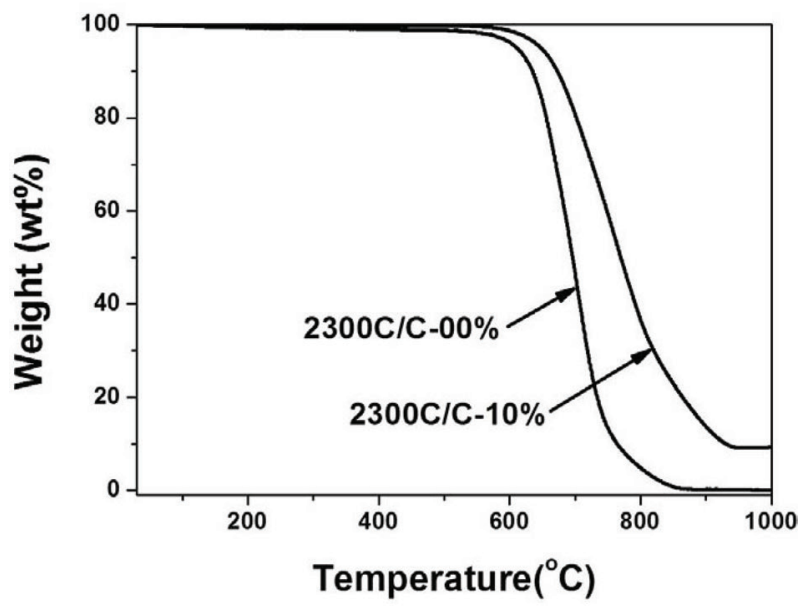

(c)

Fig. 7. Oxidation properties of the composites prepared at different heat-treatment temperatures (a) $1,000^{\circ} \mathrm{C}$, (b) $1,650^{\circ} \mathrm{C}$, and (c) $2,300^{\circ} \mathrm{C}$.

ite without illite, from $613^{\circ} \mathrm{C}$ to $643^{\circ} \mathrm{C}$. This is primarily due to increased $\mathrm{SiC}$ formation induced by the higher heat-treatment temperature. When the composite was prepared at $2,300^{\circ} \mathrm{C}$, almost all of the illite reacted to form $\mathrm{SiC}$, which is highly resis- 
tant to thermal oxidation. Therefore, the IDT significantly increased compared with the other composites with illite.

It is also important to note that the oxidation behavior of the composite prepared at $2,300^{\circ} \mathrm{C}$ was different from that of the other composites. With heat-treatment temperatures of 1,000 and $1,650^{\circ} \mathrm{C}$, shoulders were observed in the TGA curves of the composites, whereas shoulders were not observed in the TGA curves of the composites when the heat-treatment temperature was $2,300^{\circ} \mathrm{C}$. We have previously reported that these shoulders suggest a delay of oxidation and are due to improved fibermatrix interfacial adhesion, which results in fewer pores, voids, and cracks and thus hinders the diffusion of oxygen within the composite $[13,15]$. However, no shoulders were observed when the composite was heat-treated at $2,300^{\circ} \mathrm{C}$, at which all the illite reacted to form $\mathrm{SiC}$. Hence, the shoulder and the subsequent delay of oxidation may be attributed to the absorption of energy by the illite. It is also possible that the illite absorbed energy during exfoliation, as it has been previously reported that illite does not decompose at temperatures less than $1,000^{\circ} \mathrm{C}$ in air [13].

\section{Conclusions}

Several different $\mathrm{C} / \mathrm{C}$ composites were prepared at different heat-treatment temperatures, either with or without illite addition. As the heat-treatment temperature was increased, the $\mathrm{SiC}$ formation via carbothermal reduction increased until all the added illite was consumed in the case of the samples heat-treated at $2,300^{\circ} \mathrm{C}$ as a result of the intimate contact between the $\mathrm{SiO}_{2}$ in the illite and the phenol resin in the precursor or carbon fibers in the preform. The illite-containing composites prepared at all heat-treatment temperatures exhibited fewer pores, voids, and interfacial cracks than the corresponding composites without illite, resulting in larger bulk densities and lower porosities. A delay of oxidation was not observed in the illite-containing composites prepared at $2,300^{\circ} \mathrm{C}$, suggesting that the illite absorbed energy for exfoliation or other physical changes. Thus, illite may have potential applications as a filler for $\mathrm{C} / \mathrm{C}$ composites despite the low densities of the prepared composites obtained here, even at a high heat-treatment temperature of $2,300^{\circ} \mathrm{C}$; however, the thermal oxidation resistance of the resulting composites was improved. Furthermore, if illite-containing $\mathrm{C} / \mathrm{C}$ composites with densities comparable to those of typical $\mathrm{C} / \mathrm{C}$ composites can be realized in future studies, the resulting composites could readily be used in practical applications.

\section{Acknowledgements}

This research was supported by the National Space Lab (NSL) program through the National Research Foundation of Korea funded by the Ministry of Education, Science, and Technology (2010-0029006).

\section{References}

[1] Chen B, Zhang LT, Cheng LF, Luan XG. Erosion resistance of needled carbon/carbon composites exposed to solid rocket mo- tor plumes. Carbon, 47, 1474 (2009). doi: 10.1016/j.carbon. 2009.01.040.

[2] Rollin M, Jouannigot S, Lamon J, Pailler R. Characterization of fibre/matrix interfaces in carbon/carbon composites. Composites Sci Technol, 69, 1442 (2009). doi: 10.1016/j.compscitech.2008.09.023.

[3] Xuetao S, Kezhi L, Hejun L, Hongying D, Weifeng C, Fengtao L. Microstructure and ablation properties of zirconium carbide doped carbon/carbon composites. Carbon, 48, 344 (2010). doi: 10.1016/j. carbon.2009.09.035.

[4] Li C, Crosky A. The effect of carbon fabric treatment on delamination of 2D-C/C composites. Composites Sci Technol, 66, 2633 (2006). doi: 10.1016/j.compscitech.2006.03.025.

[5] Wu X, Luo R, Ni Y, Xiang Q. Microstructure and mechanical properties of carbon foams and fibers reinforced carbon composites densified by CLVI and pitch impregnation. Compos, Part A: Appl Sci Manuf, 40, 225 (2009). doi: 10.1016/j.compositesa.2008.11.007.

[6] Huang JF, Deng F, Xiong XB, Li HJ, Li KZ, Cao LY, Wu JP. High performance $\mathrm{Si}-\mathrm{SiC}$ composite coating for $\mathrm{C} / \mathrm{C}$ composites prepared by a two-step pack cementation process. Adv Eng Mater, 9, 322 (2007). doi: 10.1002/adem.200600235.

[7] Wu X, Radovic LR. Inhibition of catalytic oxidation of carbon/ carbon composites by phosphorus. Carbon, 44, 141 (2006). doi: 10.1016/j.carbon.2005.06.038.

[8] Park SJ, Cho MS. Effect of anti-oxidative filler on the interfacial mechanical properties of carbon-carbon composites measured at high temperature. Carbon, 38, 1053 (2000). doi: 10.1016/s00086223(99)00210-9.

[9] Papakonstantinou CG, Balaguru P, Lyon RE. Comparative study of high temperature composites. Compos, Part B: Eng, 32, 637 (2001). doi: 10.1016/s1359-8368(01)00042-7.

[10] Sinha Ray S, Okamoto M. Polymer/layered silicate nanocomposites: a review from preparation to processing. Prog Polym Sci, 28, 1539 (2003). doi: 10.1016/j.progpolymsci.2003.08.002.

[11] Cho HG, Kim EY, Jeong GY. Surface chemical properties of the Youngdong iiiite ore: the $\mathrm{pH}$ of zero proton charge and surface site density. J Miner Soc Korea, 14, 12 (2001).

[12] Zhou GH, Wang SW, Huang XX, Guo JK. Improvement of oxidation resistance of unidirectional $\mathrm{Cf} / \mathrm{SiO} 2$ composites by the addition of SiCp. Ceram Int, 34, 331 (2008). doi: 10.1016/j.ceramint.2006.10.008.

[13] Jeong E, Kim J, Cho SH, Kim JI, Han IS, Lee YS. New application of layered silicates for carbon fiber reinforced carbon composites. J Ind Eng Chem, 17, 191 (2011). doi: 10.1016/j.jiec.2011.02.032.

[14] Kempfer L. The many face of boron nitride. Mater Eng, 107, 41 (1990).

[15] Jeong E, Kim JH, Lee YS. New application of clay filler for carbon/carbon composites and improvement of filler effect by clay size reduction. Carbon Lett, 11, 293 (2010).

[16] Harris LA, Kennedy CR, Wei GCT, Jeffers FP. Microscopy of Sic powders synthesized by reacting colloidal silica and pitch. J Am Ceram Soc, 67, C121 (1984). doi: 10.1111/j.1151-2916.1984. tb19716.x.

[17] Lee SH, Yun SM, Kim SJ, Park SJ, Lee YS. Characterization of nanoporous $\beta$-SiC fiber complex prepared by electrospinning and carbothermal reduction. Res Chem Intermediat, 36, 731 (2010). doi: 10.1007/s11164-010-0175-9.

[18] Yajima S, Okamura K, Hayashi J, Omori M. Synthesis of continuous Sic fibers with high tensile strength. J Am Ceram Soc, 59, 324 (1976). doi: 10.1111/j.1151-2916.1976.tb10975.x. 
[19] Pujar VV, Cawley JD. Effect of stacking faults on the X-ray diffraction profiles of $\beta$-SiC powders. J Am Ceram Soc, 78, 774 (1995). doi: 10.1111/j.1151-2916.1995.tb08246.x.

[20] Koumoto K, Takeda S, Pai CH, Sato T, Yanagida H. High-resolution electron microscopy observations of stacking faults in $\beta$-SiC. J Am Ceram Soc, 72, 1985 (1989). doi: 10.1111/j.1151-2916.1989. tb06014.x.

[21] Terada K, Yonemochi E. Physicochemical properties and surface free energy of ground talc. Solid State Ionics, 172, 459 (2004). doi: 10.1016/j.ssi.2004.03.032.

[22] Yang X, Guo SJ, Chen BF, Meng F, Lian YD. Electrostatic performance of various lubricant powders in $\mathrm{P} / \mathrm{M}$ electrostatic die wall lubrication. Powder Technol, 164, 75 (2006). doi: 10.1016/j.powtec.2006.02.006.

[23] Im JS, Kim SJ, Kang PH, Lee YS. The improved electrical conductivity of carbon nanofibers by fluorinated MWCNTs. J Ind Eng Chem, 15, 699 (2009). doi: 10.1016/j.jiec.2009.09.048. 